\title{
Race: The Difference That Makes a Difference
}

\author{
Syed Mustafa Ali
}

\author{
Computing Department, The Open University, Walton Hall, Milton Keynes MK7 6AA, England. \\ s.m.ali@open.ac.uk
}

\begin{abstract}
During the last two decades, critical enquiry into the nature of race has begun to enter the philosophical mainstream. The same period has also witnessed the emergence of an increasingly visible discourse about the nature of information within a diverse range of popular and academic settings. What is yet to emerge, however, is engagement at the interface of the two disciplines - critical race theory and the philosophy of information. In this paper, I shall attempt to contribute towards the emergence of such a field of enquiry by using a reflexive hermeneutic (or interpretative) approach to analyze the concept of race from an information-theoretical perspective, while reflexively analyzing the concept of information from a critical race-theoretical perspective. In order to facilitate a more concrete enquiry, the concept of information formulated by cyberneticist Gregory Bateson and the concept of race formulated by philosopher Charles W Mills will be placed at the centre of analysis. Crucially, both concepts can be shown to have a connection to the critical philosophy of Immanuel Kant, thereby motivating their selection as topics of examination on critical reflexive hermeneutic grounds.
\end{abstract}

Keywords: Critical Race Theory, Philosophy of Information, Information Theory, Systems Theory, Race, Racism, Gregory Bateson, Charles W Mills, Immanuel Kant

Acknowledgement: I should like to thank Professors Charles W Mills and Robert Bernasconi for kindly making reprints of a number of their works available during the preparation of this article. I should also like to thank David Chapman and Magnus Ramage for the invitation to present an earlier version of this paper at the DTMD 2011: The Difference That Makes a Difference workshop that was held at The Open University (UK) during 7 - 9 September 2011. Finally, I should like to thank two anonymous reviewers for their comments on an earlier version of this paper.

According to the cyberneticist Gregory Bateson, information, or rather the elementary unit of information is "a difference that makes a difference" $(1972,459)$. Crucially, on this view, a difference is "not a thing or an event"; rather, it is an "abstract matter", and in the world of communication and organisation this "abstract matter", whose essence can be shown to lie in form and pattern, can bring about "effects" (p.458). To the extent that race constitutes a difference - perhaps the difference - that makes a difference in the world in terms of its impact on political, economic, cultural and other social concerns, it can be analysed in informational terms; however, it is what Floridi $(2002,142)$ refers to as the "information turn in philosophy" which indicates that such an analysis should be carried out ${ }^{1}$. The emergence of a global information society has placed information at the centre of contemporary intellectual discourse, motivating application of the concept in a variety of areas. It is precisely because of this "information turn" that critical ${ }^{2}$ enquiry into the nature of information becomes important, perhaps even necessary.

This paper aims at contributing towards critical enquiry into the nature of information using a reflexive hermeneutic approach to explore the differences made by - or "effects" that result from the interaction of race and information, both of which make reference to the concept of difference. First, brief overviews of recent developments within information studies and race studies are presented which indicate that although critical enquiries have been undertaken in both disciplines, reflexive engagement at the intersection of these disciplines has yet to take place. A reflexive hermeneutic approach to race and information which involves analyzing the concept of race from an information-theoretical perspective while reflexively analyzing the concept of information from a race-theoretical perspective, resulting in a hermeneutic (or interpretative) spiral, is then briefly outlined. This approach is then used to subject the concept of race, principally the systemic formulation of this concept due to the philosopher Charles W. Mills, and the concept of information, principally the Kant-inspired formulation due to Bateson, to critical enquiry. Finally, some brief conclusions and proposals for future work are presented.

1 Floridi holds that "the development of human society has now reached a stage in which issues concerning the creation, dynamics, management, and utilisation of information and computational resources are absolutely vital" $(2002,127)$.

${ }^{2}$ The term 'critical' should here be understood as having a meaning similar to the use of this term in critical theory, viz. as concerned with issues of exploitation, oppression, injustice, domination, subjugation, control, asymmetrical powerrelations etc. 
It is important to keep in mind that this work is both preliminary and exploratory in nature, its aim being to make a modest yet significant contribution to an ongoing and expanding project concerned with investigating issues at the intersection of critical race theory, computing, information theory, systems theory and cybernetics. However, before proceeding, it is important to consider how the theoretical underpinning and reflexive hermeneutic approach presented herein relates to the analysis of other phenomena such as gender discrimination, homophobia and anti-Semitism.

Some theorists, such as Omi and Winant, argue that race, class, gender (and sexual orientation) constitute interlocking "regions of hegemony" with none of them constituting a privileged site of enunciation $(1994,68)$. Others have proposed similar schemes based on the idea of 'axes' or 'dimensions' of oppression within the context of modernity ${ }^{3}$. However, the claim that there are symmetries or analogies between race, class, gender and sexual orientation vis-à-vis oppression which is advanced largely by white critical race theorists working in the discipline of 'whiteness' studies - has been challenged by a number of non-white researchers ${ }^{4}$. According to Johar Schueller, "there is no parallel in sexual oppression to the racial oppression that legitimized the enslavement of Africans in the eighteenth and nineteenth centuries (although the latter certainly included elements of sexual oppression as well); racial difference is marked on the body with a visibility not apparent in a person's different sexual practices, such as sadomasochism versus 'vanilla'. The analogical relationships [between race, class, gender and sexual orientation], however, function to suppress the specific differences introduced by race. The seeming equivalence of the analogy and the horizontal seriality suggested by the commas often used by gender [and whiteness] theorists to include concerns of race and class in routinely used phrases such as "race, class, and gender" belie a hierarchy of ontologies that privilege whiteness" $(2005,71)$.

Consistent with this position, Mills (2003) maintains that race, not class, constitutes the 'primary contradiction' and that it trumps gender in this regard. Mills advances this position while affording due recognition to the continued existence of these other forms of oppression and acknowledging that patriarchy constitutes a historically-earlier form of oppression (Mills and Pateman 2007). Postcolonial - or rather, decolonial - scholars such as Walter Mignolo, Ramón Grosfoguel and others go further to argue that the contemporary world system, which they refer to as a "colonial matrix of power", is both religiously- and racially-grounding relative to class, gender and sexual orientation.

Building on the position of Johar Schueller, Mills, Mignolo, Grosfoguel and other non-white decolonial scholars, the author of this paper takes the view that race is grounding relative to other considerations such as class, gender and sexual orientation and that issues of gender discrimination, homophobia and anti-Semitism should be subjected to critical analysis from this perspective.

\section{Critical Information Theory}

Scientific and philosophical enquiry into the nature of information has been going on for at least a century, its foundations being laid by the pioneering work of logicians and mathematicians such as Frege and Turing, and communications engineers, cyberneticists and systems theorists such as Shannon, Weaver, Wiener and Bateson among others ${ }^{5}$. It is important to appreciate at the very outset that there is no consensus as to the meaning of the term 'information': according to Rocchi

\footnotetext{
${ }^{3}$ It is interesting to note how theorists working in disciplines such as gender studies, postcolonial studies and critical theory tend to conceptualize systems of power and oppression in spatial and/or mathematical terms, e.g. 'regions', 'axes', 'dimensions', 'vectors' (Judith Butler) and 'matrices' (Walter Mignolo etc). To the extent that information can be conceived in mathematical terms (at least following Shannon), it might be argued that all such articulations are fundamentally informational in nature.

${ }^{4}$ Johar Schueller maintains that "it has become almost a given that works in gender and sexuality studies [authored by white feminist theorists] acknowledge multiple axes of oppression or invoke the mantra of race, class, gender, and sexuality" $(2005,64)$. She goes on to describe what is, in her view, "the dominant paradigm for the imperialist incorporation of women of color in contemporary gender and sexuality studies: incorporation by analogy. This strategy denies primacy to the voices of the colonized that have proclaimed the pre-eminence of the racial difference" (2005, 65, emphasis added). Significantly, Schueller points to the "epistemological function of analogy" and "the political role of analogy as epistemology" $(2005,67)$ and argues for the necessity of enquiring as to "who is doing the analogizing and to what purpose". On her view, "the analogizing move within white feminist theory ... may constitute a neo-colonial movement more dangerous than the earlier absence of race and, thus, may need close scrutiny". (2005, 68) This is because "racial analogy in white feminist/gender/sexuality studies functions as a colonial fetish that enables the (white) theorist to displace the potentially disruptive contradictions of racial difference onto a safer and more palatable notion of similarity, thus offering theory that can be easily assimilated within the politics of liberal multiculturalism" $(2005,72)$. On a related note, and following Hesse (2011), it might be argued that conceptualising race in biological terms and in a European context has resulted in anti-Semitism being placed in the analytical foreground of race discourse while non-European - that is, colonial - formations of race are moved into the background.

${ }^{5}$ Ramage (2011) provides an interesting overview of the various competing Western perspectives on information within the history of cybernetics. For detailed historical accounts of the development of information and cybernetics in US and Soviet contexts, readers are referred to works by Heims (1993) and Gerovitch (2002) respectively.
} 
(2011), more than twenty-five different theories of information can be identified in the period from 1948 to 2009. These include the mathematical - which for many researchers, means purely quantitative and syntactic - theory of information (often abbreviated to MTC, mathematical theory of communication) due to Shannon and Weaver $(1949)^{6}$; the ecological theory of information due to Bateson (1972); and the autopoietic theory of information due to Maturana and Varela (1980). Recently, a number of more explicitly philosophical conceptualisations of information have begun to appear including the semantic theory of information due to Floridi (2004a), and what profess to be proto-scientific theories of information as formulated by Capurro and Hjørland (2003), Capurro (2009) and Hofkirchner (2009; 2011a; 2011b).

However, philosophy of information (PI) as a distinct discipline in its own right owes its conception to the philosopher Luciano Floridi who for the last decade, and in an ever-expanding series of works, has attempted to clarify the different senses of this term, delineate its boundaries and identify its problematic concerns (Floridi 2002; 2003; 2004a; 2004b; 2009; 2010a; 2010b). According to Floridi, "PI deals with three types of domain: topics (facts, data, problems, phenomena, observations, and the like); methods (techniques, approaches, and so on); and theories (hypotheses, explanations, and so forth)" $(2002,126)$, and may be defined as follows: "The philosophy of information (PI) is the philosophical field concerned with (a) the critical investigation of the conceptual nature and basic principles of information, including its dynamics, utilisation, and sciences, and (b) the elaboration and application of information-theoretic and computational methodologies to philosophical problems" $(2002,137)$.

Floridi maintains that "PI is not only a new field but provides an innovative methodology as well. Research into the conceptual nature of information and its dynamics and utilisation is carried on from the vantage point represented by the methodologies and theories offered by ICS [or Information and Computational Sciences] and ICT. This perspective affects other philosophical topics as well. Information-theoretic and computational methods, concepts, tools, and techniques have already been developed and applied in many philosophical areas" $(2002,139)$. It is precisely for this reason that it is important, perhaps even necessary, to consider whether $\mathrm{PI}$, or some other philosophy of information, might legitimately be applied to critical race theoretical enquiry from a hermeneutic perspective ${ }^{7}$. For example, according to Floridi, "PI provides critical investigations that are not to be confused with a quantitative theory of data communication (information theory). On the whole, its task is to develop not a unified theory of information but rather an integrated family of theories that analyse, evaluate, and explain the various principles and concepts of information, their dynamics and utilisation" (2002, 137, emphasis added). Significantly, he maintains that "in philosophy ... virtually any issue can be rephrased in informational terms" $(2002,139)$; however, Floridi also insists that "although many philosophical issues seem to benefit greatly from an informational analysis, in PI information theory provides a literal foundation, not just a metaphorical superstructure. PI presupposes that a problem or an explanation can be legitimately and genuinely reduced to an informational problem or explanation" (2002, 140, emphases added). Given the reflexive hermeneutic approach to considering issues at the intersection of race and information argued for herein, it is questionable to what extent PI can - or should - be considered capable of providing a foundation for critical enquiry into information ${ }^{8}$.

\footnotetext{
${ }^{6}$ Floridi maintains that "since MTC is a theory of information without meaning, and information minus meaning = data, mathematical theory of data communication is a far more appropriate description than information theory" (2004a, 52), a position that derives support from Weaver's insistence that "MTC deals with the carriers of information, symbols and signals, not with information itself" (Weaver 1949 cited in Floridi 2004a, 52). Floridi further states that "the [MTC] approaches information as a physical phenomenon. Its central question is whether and how much uninterpreted data can be encoded and transmitted efficiently by means of a given alphabet and through a given channel. MTC is not interested in the meaning, aboutness, relevance, usefulness, or interpretation of information, but only in the level of detail and frequency in the uninterpreted data, being these symbols, signals or messages" (2004a, 53). Similarly, Capurro maintains that the MTC "does not deal with communication as transmission of meaning or with information as the meaning of a message. It is a theory of the codification and transmission of messages" $(2009,131)$. Nonetheless, this view has not gone uncontested. For example, Chapman has argued that the concept of information in MTC can, in fact, be shown to be semantic (or meaningful) by drawing on parallels between insights into the layered architectures used by communications engineers and semiotic concepts of meaning. However, as Chapman concedes, this is only possible by making use of "a definition of meaning based on a rather mechanistic interpretation of the meaning of semiotic signs" $(2011,49)$, and additionally, it might be argued, on the basis of a conflation of mind with brain, and anthropomorphism with respect to encoding operations in the layered architecture, viz. signals being "taken to mean" something (but by whom?)

7 This position finds additional support in Floridi's claim that "informational and computational concepts, methods, techniques, and theories had become powerful metaphors acting as 'hermeneutic devices' through which to interpret the world. They had established a metadisciplinary, unified language that had become common currency in all academic subjects, including philosophy" $(2002,129)$.

${ }^{8}$ Floridi maintains that "research into the conceptual nature of information and its dynamics and utilisation is carried on from the vantage point represented by the methodologies and theories offered by ICS and ICT This perspective affects other philosophical topics as well. Information-theoretic and computational methods, concepts, tools, and techniques have
} 
In contrast to Floridi's proposal for an integrated family of information theories, Hofkirchner (2009; 2011a; 2011b) proposes a Unified Theory of Information (UTI) grounded in an emergent materialism ${ }^{9}$ that allegedly goes some way toward resolving problems resulting from the lack of reflexivity associated with $\mathrm{PI}$. This is done by appealing to a framework that is structuralist, hierarchical and dialectical which, it is claimed, provides the scientific means by which to integrate various domains of human existence. According to Hofkirchner, "it is malfunctions in the sociosphere, ecosphere and technosphere that continue to aggravate the global challenges. And it is information that turns out the only remedy. It is information that is required to steer society. It is information that is required to reorganise humanity onto a higher level of organisation ... Information is the conditio sine qua non for the further existence and development of humanity" (2009, 359, emphases added). It is important to appreciate that in conceiving (information) science in dialectical terms, a commitment to critical theory and some form of Marxist and/or Hegelian metaphysics is implied ${ }^{10}$.

Recent works by Lash (2002), from a social-science perspective, and the edited collection by Leckie et al. (2010) in the field of library and information science, provide further evidence of engagement at the interface of critical theory and information studies. However, perhaps the most important since most overtly ideological ${ }^{11}$ - perhaps even polemical - of such works from the perspective of this study is an article by Christian Fuchs entitled "Towards a critical theory of information" (Fuchs 2009) which purports to address issues of race, gender and class in the context of a neo-Marxist dialectical framework ${ }^{12}$. Although Fuchs' critical theory of information is both interesting and relatively well-developed, it is crucial to appreciate that it assumes the legitimacy of a class-based historically-materialist analysis of power relations, domination and oppression in which economic concerns are considered basic while other concerns, such as those relating to gender and race, are taken to be superstructural in the sense of non-foundational. This approach contrasts strongly with other historically-materialist interpretations of socio-political reality focusing on asymmetric power relations such as the contractual framework proposed by Mills and Pateman (2007) in which race, racism and processes of racialization are viewed as grounding systemic concerns against which issues relating to gender and class must be addressed. To the extent that existing critical information theory is grounded in critical theory, and to the extent that the latter is fundamentally Marxist/class-based in orientation, drawing heavily on the works of thinkers in the Frankfurt school such as Adorno, Horkheimer and Marcuse, it appears to offer little in the way of resources for critical race theoretical enquiry into the nature of information ${ }^{13}$.

Consistent with the reflexive hermeneutic approach to analysis presented herein, and having briefly examined information theory from a critical perspective, it is necessary to shift the focus of enquiry to consideration of race theory from a critical perspective.

already been developed and applied in many philosophical areas" $(2002,139)$. However, this position fails to appreciate the need for considering a reflexive move from philosophical topics - including those which are largely 'invisible' to the Western philosophical canon such as critical race theory - and to the philosophy of information.

${ }^{9}$ It is interesting to note in this regard that Floridi's General Definition of Information (GDI) (2004a) is metaphysically agnostic in that it does not require a commitment to materialism or realism. This is significant since as Van Cleve (1990), Griffin (1998) and others have argued, contrary to Hofkirchner's assertions, the explanatory status of emergent materialism is not unproblematic. In particular, the "hard problem" of consciousness (Chalmers 1996), viz. how ontological-subjectivity (experiential first-personhood) can emerge from an ontologically-objective (third-person, non-experiential) substrate looms large, proposed dialectical resolutions of this problem involving the (re-)interpretation of mind as an emergent property or event "of a different materiality" (Hofkirchner 2009, 363) notwithstanding.

${ }^{10}$ Evidence supporting this assertion is provided by explicit references to Marx and Hegel in Hofkirchner (2009). This is significant from a critical race theoretical perspective since as Eze (1997), Bernasconi (2003b), Tibebu (2011) and others have shown, Hegel's philosophy of history is both Eurocentric and racist. It remains to be determined to what extent, if at all, Hegel's historical racism impacts on his dialectic.

${ }^{11}$ Given Fuchs' commitment to a Marxist interpretation of the term 'ideology' and his belief that some variant of neoMarxism provides the necessary and sufficient foundations for a scientific (meaning 'true') conception of reality, this classification would probably be rejected by him. However, to the extent that the metaphysical status of neo-Marxist accounts of reality remains contestable, such criticism begs the question.

${ }^{12}$ Unfortunately, limitations of space preclude the possibility of presenting a more detailed critical race theoretical analysis of Lash's critique of information and Fuchs' critical theory of information at this time. A preliminary attempt at such a critique was presented at the $4^{\text {th }}$ ICTs and Society Conference held at Uppsala University, 2-4 May 2012 (Ali 2012).

${ }_{13}$ In this connection, it is important to note that non-European scholars working in the field of postcolonial - more precisely, decolonial - studies such as Walter Mignolo (2010) have similarly questioned the relevance of Frankfurt school thinking for critical projects concerned with emancipating (i.e. decolonising) epistemology. On their view, Marxist/Hegelian dialectic and Frankfurt school discourse on the issue of modernity are both fundamentally Eurocentric in orientation, masking the hegemonic operation of a "dark underside", viz. coloniality or the "colonial matrix of power". 


\section{Critical Race Theory}

Although scholarly enquiry into the nature of race ${ }^{14}$ has been going on within the Western tradition for the last few centuries, it is only relatively recently that critical discourse about race and racism has surfaced within the mainstream of academic philosophy ${ }^{15}$. Following the pioneering lead of Eze (1997), a number of studies have appeared during the last two decades subjecting the works of major Enlightenment figures such as Descartes, Hobbes, Hume, Locke, Rousseau, Kant and Hegel, and post-Enlightenment figures such as Nietzsche and Heidegger, to detailed scrutiny. Examples of such works include collections edited by Bernasconi (2001a), Boxill (2001), Ward and Lott (2002), Bernasconi and Cook (2003), Levine and Pataki (2004), Valls (2005), and the fourvolume collection edited by Taylor (2011). Studies from a critical theory perspective have also appeared including the edited collection by Harris (1999) and the sociologically-informed criticalrealist investigation of race and racism by Carter (2000). More recently, a number of what might be designated as critical race-theoretical enquiries into race have been conducted by philosophers including Outlaw (1996), Mills $(1997 ; 1998 ; 2003)$ and Taylor $(2004)^{16}$. While it is true that the majority of such investigations are framed in terms of the Anglo-American analytic tradition within philosophy, there have been some notable exceptions: for example, the collections edited by Bernasconi (2001a) and Bernasconi and Cook (2003) examine race and racism within the continental tradition of philosophy, focusing on phenomenological and hermeneutic concerns as well as the works of major philosophers identified with this tradition (e.g. Nietzsche, Heidegger and Sartre). With regard to scholarly output in academic journals and conference proceedings, the situation is even more promising, with an increasingly large body of work addressing race from a number of perspectives being generated by philosophers working within a range of traditions, including those that are critically-informed.

Despite these positive developments, there has been little in the way of philosophical enquiry into race from the perspective of information and systems theory. Where race is engaged with from an informational perspective, such enquiry tends to be more sociologically rather than philosophically informed, and generally focuses on the following issues: (i) differential access to ICTs and the so-called "Digital Divide" ${ }^{17}$; (ii) representation of and power relations between different ethnic and racial groups within information spaces such as social networks and virtual worlds ${ }^{18}$; (iii) the harnessing of digital technologies for the promotion of white nationalist/supremacist agendas ${ }^{19}$; and (iv) non-white - more specifically, non-white African and African-American - contributions to and appropriations of cybernetics and systems theory ${ }^{20}$. What remains largely, if not entirely, unexplored is the possible contribution that information theory, systems theory and cybernetics can make to an understanding of race, racism and processes of racialization ${ }^{21}$. Perhaps the closest there is to something along these lines is Fuller, Jr.'s systems-theoretical formulation which defines race (and racism) in the following self-referential (or circular) terms ${ }^{22}$ : "DEFINITION: a system of

\footnotetext{
${ }^{14}$ Race is a concept that is notoriously hard to define and there is perhaps even less consensus as to its meaning than there is in the case of information. Banton defines a race as "a group or category of persons connected by a common origin" and maintains that the term "came to be used in the sense of type as designating species of men distinct both in physical constitution and mental capacities"; however, he insists that "the main issue is not what 'race' is but the way it is used" $(2004,333)$. On this basis, race has come to be viewed as a social construct rather than a natural (or biological) given, "a shifting signifier that means different things to different parties at different points in history [which] defies definitive explication outside specific contexts" (Van Den Berghe 2004, 334). At this point in the discussion, race should be understood as referring to a phenomenon that is historically-contemporaneous with, and genealogically related to, the practice of racism which may be understood, loosely, in terms of patterns of discrimination based on physical markers that reflect asymmetrical relations of power and privilege, oppression, domination and exploitation.

${ }^{15}$ In academic sociology, the situation is somewhat different in that race (latterly ethnicity), along with class and gender, has been a focus of enquiry for a much longer period and has received a large amount of scholarly attention, both with respect to empirical studies and theoretical framings of the concept. Representative works in the sociological literature on race and racism include Banton (1998), Miles and Brown (2003) and Rattansi (2007).

${ }^{16}$ It is crucial to appreciate that I am using the phrase "critical race-theoretical" in a somewhat different sense to how this term is generally understood. In its original formulation, Critical Race Theory (CRT) is an academic discipline examining issues at the intersection of race, law and power. According to Nakamura and Chow-White, CRT "investigates the shifting meanings of race and how it works in society, and proposes interventions in the name of social justice" (2001b, 5).

${ }^{17}$ See Compaine (2001), Moss (2002), Warschauer (2003) and Hargittai (2008) for examples of such studies.

${ }^{18}$ In this connection, see Kolko et al. (2000), Nakamura (2002; 2007) and Nakamura and Chow-White (2011a).

${ }^{19}$ Works of this type include Back (2002) and Daniels (2009).

${ }^{20}$ Key works include Eglash (1995) and Eglash and Bleecker (2001) among others.

${ }^{21}$ One (partial) exception in this regard is the seminal essay "Encoding and Decoding in the Media Discourse" by cultural theorist and sociologist, Stuart Hall (1973); however, it is important to appreciate that this work draws on the semiotics of communication rather than information theory as such.

${ }^{22}$ Self-referential definitions are common within disciplines that embrace reflexivity. Consider, for example, Maturana and Varela's concept of an autopoietic (or self-producing) system within second-order cybernetics: "An autopoietic machine is a machine organized (defined as a unity) as a network of processes of production (transformation and destruction) of
} 
thought, speech, and action, operated by people who classify themselves as 'white', and who use deceit, violence, and/or the threat of violence, to subjugate, use, and/or abuse people classified as 'non-white', under conditions that promote the practice of falsehood, non-justice, and incorrectness, in one or more areas of activity, for the ultimate purpose of maintaining, expanding, and/or refining the practice of White Supremacy (Racism)" $(1984,301)$

According to Fuller Jr., racism, which on his view is identical to white supremacy, is a global system composed of nine major areas of activity or subsystems, viz. economics, education, entertainment, labour, law, politics, religion, sex and war. This systems-theoretical formulation is important since it constitutes a contribution towards an information-theoretical framework for thinking about race that is also critically race-theoretical in orientation. In this regard, it represents a radical alternative to systemic frameworks based on the critical theoretical perspectives of thinkers such as Giddens, Bourdieu and Habermas, each of whom takes economics, politics and culture to be primitive (or 'core') subsystems in a capitalist systemic whole. In addition, whereas critical theories of information as formulated by Lash (2002), Fuchs (2009) and others take capitalism to define the nature of the world system, Fuller Jr. considers that it is racism (or white supremacy) which assumes this role. This is important since a critical perspective on information based on a critical race theory of this kind presents the possibility of a fundamentally different type of critique.

\section{A Reflexive Hermeneutic Approach to Race and Information}

In order to engage critically with issues at the intersection of race and information, one obvious approach might be to consider how critical enquiry associated with one field can be related to critical enquiry associated with the other. This would entail analyzing critical race theory from a critical information-theoretical perspective and analyzing critical information theory from a critical racetheoretical perspective. Importantly, since neither theory can - or rather, should - be taken, a priori, as grounding ${ }^{23}$ relative to the other, the analyses would have to be understood as standing in reflexive (or circular) relation, resulting, thereby, in a hermeneutic (or interpretative) spiral of enquiry. In addition, it is important to recognize that critical race theory and critical information theory are not fields of enquiry whose terms of reference are universally agreed upon; on the contrary, what counts as critical race theory and what counts as critical information theory are, arguably, highly contestable, if not highly contested, issues, reflecting different agendas and, significantly, differential power relations among theoreticians ${ }^{24}$. Furthermore, the issue of contestation should be understood to apply a fortiori to the concepts motivating both of these critical enquiries since, as is the case with so many terms of analysis, there are no universally agreed upon definitions or concepts of race and information ${ }^{25}$.

Given the adoption of a reflexive hermeneutic approach, what this means is that analysis of race from a critical information-theoretical perspective and analysis of information from a critical race-theoretical perspective must proceed by selecting an exemplary formulation of each concept which is then placed in the foreground so as to motivate enquiry on a concrete basis, while maintaining awareness of the fact that other related formulations have been placed in the analytical background ${ }^{26}$. While any such selection might be viewed as somewhat arbitrary (or subjective) at the start of enquiry, the rationale for selection needs to be established and made transparent nonetheless. To this end, and given the provisional nature of this study, the concept of information formulated by cyberneticist Gregory Bateson and the concept of race formulated by political philosopher Charles W Mills will be placed in the analytical foreground. The rationale for selecting these particular formulations of information and race is that both can be shown to have a connection to

components which: (i) through their interactions and transformations continuously regenerate and realize the network of processes (relations) that produced them; and (ii) constitute it (the machine) as a concrete unity in space in which they (the components) exist by specifying the topological domain of its realization as such a network" $(1980,78)$.

${ }^{23} \mathrm{Here}$, the term 'ground' is taken to refer either to a base (or foundation) or, alternatively, to a cause (or determinant).

${ }^{24}$ Mills $(1997 ; 2003)$ points out that mainstream academic philosophy is overwhelmingly 'white', both with respect to the selection of works that are taught and made the subject of scholarly research activity, and also with regard to the composition of faculties at academic institutions. I maintain that the situation within critical race theory and critical information theory is similar, the former being dominated by discourses about 'whiteness' and 'white privilege', and the latter by a shared commitment to some variant of Marxism as evidenced by Lash (2002) and Fuchs (2009).

${ }^{25}$ Following Hofkirchner (2011a), it might be argued that this is true for information because a science of information based on some form of hierarchical and unified theory of information (UTI) has yet to emerge; however, Floridi, who is committed to an approach based on a non-hierarchical "distributed network of connected concepts linked by mutual and dynamic influences that are not necessarily genetic or genealogical" which foregrounds "epistemically oriented semantic information" considers UTI to be, ultimately, both reductionist and "unlikely to succeed". (2004a, 41)

${ }^{26}$ This approach is informed by a phenomenological perspective which, following Husserl, requires the analyst to go "back to things themselves" and treat concepts as phenomena; however, no commitment to a specific phenomenological orientation, irrespective of whether this is Husserlian, Heideggerian or something else, is entailed thereby. 
the critical philosophy of Immanuel Kant, thereby motivating their foregrounding as intersecting subjects (objects, topics, phenomena) of enquiry on critical reflexive hermeneutic grounds ${ }^{27}$.

\section{Race: A Critical Information-Theoretical Perspective}

According to Capurro (2009), the term information, at least in its original Greek-Latin and Medieval usage, originally had two meanings: (i) an objective meaning ("giving form to something") and (ii) a communicational meaning ("telling something new"). Consistent with this position, von Bayer (2003) maintains that information should be understood as both inform-ation and information, that is, as involving both the transmission of meaning and the transfer of form (arrangement, configuration, order, organisation, pattern, shape, structure and relationship). Crucially, on his view, "the meaning of a message arises out of the relationship of the individual symbols that make it up" (Bayer 2003, 19).

Irrespective of whether or not certain types of patterns (forms, structures) - and hence, information - can be taken to exist, and certain transformations of patterns by other patterns can be said to occur, in the non-human sphere independently of human consciousness ${ }^{28}$, Floridi (2004a) has shown that it is quite possible for information to exist in the human sphere in the absence of an informed subject even if an informer is necessary for the production of such information in the first instance. This is significant because the ontological status of certain patterns in the human world for example, patterns of discrimination (prejudice) and/or domination (power) associated with racial difference - are generally taken to be both socially-constructed and causal (that is, they "make a difference" or have "effects") ${ }^{29}$, yet it is unclear whether such patterns exist independently of consciousness. Some philosophers of race, such as Garcia (1996), maintain that racism should be understood in individualistic terms and as fundamentally moral, attitudinal, intentional and volitional in nature; others, such as Shelby (2002), argue that race is essentially cognitive in nature, and that racist beliefs provide necessary and sufficient conditions for racism. However, all such accounts, irrespective of whether framed in terms which refer to the "heart" (morality) or those that refer to the "head" (beliefs), make consciousness a necessary condition for racism.

\subsection{Race as a system}

While sympathetic to cognitive accounts of racism, Mills $(1997 ; 1998 ; 2003 ; 2005 ; 2007)$ insists that racism can - and does - exist in a purely structural (or pattern-based) capacity, that is, in terms of differentially-embedded power relations that are at least not explicitly intentional, that is, dependent on consciousness for their continued existence. Put another way, racism can exist in the absence of informed subjects who are conscious of their racist beliefs and practices, although subjects who are conscious of their racist beliefs and practices - racist informers - are necessary for the production of racism in the first instance. This is possible because Mills maintains that patterns of discrimination and/or domination associated with racial difference - that is, racism - should not be understood as the exceptional behaviour of individuals deviating from a non-racist social norm, but rather, as a global socio-political system ${ }^{30}$ that is both historical and material in nature. On Mills' view, racism - more precisely, global white supremacy - is a political system, a particular power structure of formal or informal rule, socioeconomic privilege, and norms for the differential distribution of material wealth and opportunities, benefits and burdens, rights and duties. Crucially, Mills maintains that white supremacy can be theorised as a "contract" between whites - a Racial Contract - which he proceeds to define as follows: The Racial Contract is that set of formal or informal agreements or meta-agreements (higher-level contracts about contracts, which set the limits

\footnotetext{
${ }^{27}$ Shannon's concept of information might have been selected on account of its widespread appeal and impact on philosophical analysis. However, it has been rejected here on the grounds that, as stated previously, the concept is generally understood to be quantitative and syntactic in nature, being concerned with the codification and transmission of messages and signals. Nonetheless, to the extent that racialization, which may be taken to refer to "any process or situation wherein the meaning of 'race' is introduced to define and given meaning to some particular population, its characteristics and actions" (Miles 2004, 348), necessarily involves racial coding (or codification), that is "a process through which people, objects and events are understood, communicated and given meaning" (Malik 2004, 341), Shannon's concept of information might, in fact, be highly relevant for critical information theoretical enquiry into the nature of race, albeit in the context of analysing race and racism with respect to how they are communicated.

${ }^{28}$ This metaphysical thesis might be described as information realism.

${ }^{29}$ An exclusively epistemological interpretation of Bateson's formulation of information (or rather its basic unit) such as the one proposed by Floridi, viz. "a 'difference' is just a discrete state (that is, a datum), and 'making a difference' simply means that the datum is 'meaningful', at least potentially" (2004a, 44-45), is, therefore, rejected.

${ }^{30}$ Race and racism are increasingly being interpreted as systemic phenomena and various accounts have been given of the historical origins and contemporary nature of the modern racial world system including those by Winant $(2001 ; 2004)$ and Goldberg (2002).
} 
of the contract's validity) between the members of one subset of humans, henceforth designated by (shifting) "racial" (phenotypical/genealogical/cultural) criteria C1, C2, C3... as "white", and coextensive (making due allowance for gender differentiation) with the class of full persons, to categorise the remaining subset of humans as "nonwhite" and of a different and inferior moral status, subpersons, so that they have a subordinate civil standing in the white or white-ruled polities the whites either already inhabit or establish or in transactions as aliens with these polities, and the moral and juridical rules normally regulating the behaviour of whites in their dealing with one another either do not apply at all in dealings with nonwhites or apply only in a qualified form (depending in part on changing historical circumstances and what particular variety of nonwhite is involved), but in any case the general purpose of the Contract is always the differential privileging of the whites as a group with respect to the nonwhites as a group, the exploitation of their bodies, land, and resources, and the denial of equal socioeconomic opportunities to them. All whites are beneficiaries of the Contract, though some whites are not signatories" (Mills 1997, 11).

Analogous to Floridi's hint that informers (or informing subjects) are necessary for the production of information, whereas informed subjects are merely contingent, Mills maintains that consciousness was necessary at the time of "signing" the Racial Contract in that, to paraphrase Bateson, a "very limited number" of (racial) differences were intentionally selected by those responsible for establishing the modern racial world system; however, subsequent to its establishment (or production), the system has been maintained by what Mills refers to as an "inverted epistemology, an epistemology of ignorance, a particular pattern of localised and global cognitive dysfunctions (which are psychologically and socially functional)" which involve "white misunderstanding, misrepresentation, evasion, and self-deception on matters related to race" $(2004 a, 18-19)^{31}$. Such an epistemology results in the emergence of subjects whose behaviour and practices are systemically racist without being explicitly intentional, or, stated in terms of critical information theory, in the emergence of information - more precisely, an informational system (racism) - that can exist in the absence of informed subjects (conscious racists).

To the extent that information is concerned with differences that make a difference (Bateson 1972) and involves a process of inform-ing - that is, transmission of meaning (von Bayer 2003) which can turn out to be a process of mis/disinform-ing, it might be argued that the 'signing' (establishment) and subsequent 're-signing' (maintenance, expansion and refinement) of the Racial Contract of white supremacy constitute informational processes.

\subsection{Race as a process}

Notwithstanding the importance of systemic accounts of race and racism, Hesse argues that critical race theoretical perspectives such as the contractualist position articulated by Mills tend to involve "a residual empiricist reliance on the reduction of race in analysis to visible, corporeal difference" $(2007,645)$, that is, physical characteristics or "markers" such as colour located on the human body. According to Hesse, rather than being necessarily correlated with the presence (or absence) of material markers on the body, "racialization [is] embodied in a series of onto-colonial taxonomies of land, climate, history, bodies, customs, language, all of which became sedimented metonymically, metaphorically, and normatively, as the assembled attributions of race" $(2007,658-$ 659). In short, while embodiment, in the broad sense of materiality (or physicality), is a necessary condition for race, such embodiment can assume - and, historically, has assumed - different forms including those that are religious, 'scientific' and cultural (Blaut 1992). To paraphrase the cultural theorist and sociologist Stuart Hall, it might be said that "race is a shape-shifting signifier" ${ }^{32}$. To the extent that information is concerned with differences that make a difference and involves a process of in-forming or transfer of form (von Bayer 2003) - that is, implanting form or, alternatively, allowing form to become sedimented - it might be argued that the "series of taxonomies" (or successive systems of hierarchical classification associated with the process of racial formation, i.e. racialization) constitutes an informational process. This position derives support from Bateson's assertion that "there are differences between differences. Every effective difference denotes a demarcation, a line of classification, and all classification is hierarchic. In other words, differences are themselves to be differentiated and classified" $(1972,324)$

\footnotetext{
${ }^{31}$ According to Mills (1997), the Racial Contract (i) prescribes norms for cognition, (ii) motivates the selection of facts; and (iii) determines what counts as information.

${ }^{32}$ Hall (2002) describes race as a "floating signifier". From the perspective of the reflexive hermeneutic approach to race and information presented herein, comparing and contrasting Hall's formulation with the Lacan-inspired notion of information as a "flickering signifier" presented by Hayles (1999) constitutes a hermeneutic enquiry that is both interesting and relevant.
} 


\section{Information: A Critical Race-Theoretical Perspective}

In the course of clarifying what is meant by the philosophy of information (PI), Floridi makes the following interesting statement ${ }^{33}$ : "An excessive concern with the metatheoretical aspects of PI may lead one to miss the important fact that it is perfectly legitimate to speak of PI even in authors who lived centuries before the information revolution. Hence, it will be extremely fruitful to develop a historical approach and trace Pl's diachronic evolution, so long as the technical and conceptual frameworks of ICS are not anachronistically applied but are used to provide the conceptual method and privileged perspective to evaluate in full the reflections that were developed on the nature, dynamics, and utilisation of information before the digital revolution" (2002, 138-139).

Consistent with this position, in what follows, one seminal conceptualisation of information that is a historical (or diachronic) antecedent of PI will be subjected to hermeneutic enquiry from a critical race theoretical perspective.

\subsection{Bateson, Kant and Race}

In Steps to An Ecology of Mind (1972), Gregory Bateson maintains that information, or rather, the elementary unit of information, is "a difference that makes a difference" $(1972,459)$. Crucially, in framing his concept of the basic unit of information, Bateson makes reference to Kant's assertions, in the Critique of Judgement, that the most elementary aesthetic act is the selection of a fact, and that there are an infinite number of potential facts associated with a thing. On this basis, Bateson is led to assert that there are an infinite number of differences associated with a thing, and that information for someone (or something) refers to a "very limited number" $(1972,459)$ of such differences selected from this infinite set. The differences that are selected make a difference to someone (or something) in that they are regarded as significant in some context; hence, Bateson's concept of information is fundamentally both contextual and causal in nature - a fact that can be shown to have widespread and profound implications for its application in the social world.

The influence of Kantian epistemology - more specifically, Kant's views on how facts are selected - on Bateson (and Floridi, Capurro, Hofkirchner and others) may be significant in more than one regard. This is because in addition to being one of the most important metaphysical, moral and political philosophers of the modern period, Kant, as lecturer in anthropology and physical geography, is also responsible for originating the modern 'scientific' concept of race and was, himself, a racist (Eze 1997; Bernasconi 2001b; 2003a; 2011; Larrimore 1999; 2008) ${ }^{34}$.

In his defence, Kantians such as Louden (2000) and Hill Jr. and Boxill (2001) have attempted to show that Kant's racism, while regrettable, is merely empirical and that it has a peripheral status which does not impact significantly on the rational core of his philosophy; others such as Kleingeld (2007) have argued that Kant gradually abandoned racism in favour of a cosmopolitan perspective during the course of developing his critical philosophical project. Unfortunately for Kant's defenders, however, Larrimore (2008) and Bernasconi (2011) have demonstrated, quite convincingly, that Kant's cosmopolitanism can be reconciled with his racism, and that there is no indication that he abandoned a commitment to racism at any point in his philosophical career. Furthermore, and more importantly in the context of the present discussion, the extent to which Kant's racism may, in fact, impact on his overall philosophical project, including his epistemology, cannot be said to a settled matter.

For this reason, it is legitimate, perhaps even necessary, to investigate the extent to which Kantian epistemology is racialized and, as a corollary, to what extent, if at all, the concept of information, at least as formulated by Bateson, is also racialized from a critical theory perspective. Both Bateson's concept of information, and Kant's concept of aesthetic judgement which inspired it, are fundamentally teleological (or goal-oriented) in that they appeal to selection which is a purposeful act; however, whereas Kant's teleology can readily be shown to be grounded in a racist anthropology, the situation is, arguably, somewhat less clear in the case of Bateson.

For example, Bateson's defenders might point to the distinction he makes between what he calls "Occidental Epistemology" (or OE) and cybernetic epistemology (CE), in Bateson (1972), and argue that Kant's epistemology is an instance of the former. However, this move is problematic on a number of counts. Firstly, Bateson nowhere explores the connections between Kant, epistemology, race and information, nor does he explicitly identify Kant's epistemology as an instance of OE;

\footnotetext{
${ }^{33}$ This statement is significant since Floridi, along with other contemporary philosophers and systems theorists such as Capurro and Hofkirchner, makes reference to the thinking of a number of major thinkers within the Western philosophical tradition including Descartes, Kant and Hegel.

${ }^{34}$ According to Eze (1997), Kant lectured more on anthropology and physical geography than on moral philosophy, and was responsible for introducing these subjects into German universities based on his own research.
} 
secondly, Kantian epistemology is often appealed to in formulating cybernetic conceptions of knowing, which means that identifying it as an instance of $O E$ is, at a minimum, a questionable move; thirdly, Bateson's distinction between OE and CE is itself contestable. If Heidegger (1977) is correct that the essence of the (post-)modern epoch may be identified with what he refers to as "cybernetic totalism" and that this is the destiny of 'The West' (that is, the Occident), it would seem to follow that contrary to Bateson, CE, rather than standing in opposition to OE, is, in fact, its next historical phase ${ }^{35}$. Similar to the way that Larrimore (2008) has shown Kant to posit the white race as both a race among races and yet transcending race (to whiteness), it might be argued that "cybernetic totalism" - perhaps even cybernetics per se - is a kind of post-humanism that both transcends and yet remains essentially grounded in the Western Enlightenment humanist project. With respect to Bateson's epistemology, this would mean that CE is both OE and post-OE. On this basis, it becomes necessary to enquire as to whether - or rather, to what extent - mainstream (or dominant) conceptions of cybernetics, systems theory and information theory, even in their 'critical' forms, are yet further instances of the Occidental/Western - which here means white/Eurocentric particular presenting itself, that is, masquerading, as the universal? ${ }^{36}$

According to Heims, "cybernetic ideas can be applied in the most diverse ideological contexts" $(1993,180)$. For example, cybernetic formulations have been used to justify both centralizations and decentralizations of power, to reconcile decentralized control with centralized purpose (under Soviet Communism), and to articulate functional analyses of the status quo (under American capitalism). However, despite their ideological diversity, such applications remain Eurocentric, both in terms of their point of origin and in terms of their expansive/totalizing scope. In this sense, cybernetics is fundamentally Eurocentric and hence, arguably white supremacist in nature, notwithstanding the allegedly 'abstract' structural-functional terms within which it is articulated ${ }^{37}$. On this view, cybernetics and informatics should be considered racial formations and the allegedly 'abstract' and impartial/neutral stance associated with them should be understood as masking the operation of racism or white supremacy. This entails considering "information" and the thinking that views itself as proper to it from a critical race theoretical perspective as historical formations that have been and still are complicit in the perpetration and perpetuation of various historical injustices.

In light of the above, it becomes legitimate - perhaps necessary - to enquire as to whether Bateson was simply being naïve in basing his concept of information on Kantian foundations or, following Mills $(1997 ; 2007)$, whether, as a white beneficiary within a system of global white supremacy, he was blinded to consideration of such concerns by an "epistemology of ignorance".

\subsection{Race and Epistemology}

In formulating his General Definition of Information (GDI) as data + meaning, i.e. objective semantic content composed of a collection of data that are well-formed and meaningful, Floridi proceeds to define a datum as a "lack of uniformity between two signs". On his view, "a datum is a relational entity" and its definition "leaves underdetermined not only the logical type to which the relata belong, but also the classification of the relata" (2004a, 43). Floridi further maintains that "a datum is usually classified as the entity exhibiting the anomaly, often because the latter is perceptually more conspicuous or less redundant than the background conditions" (2004a, 43, emphasis added). From a critical race theoretical perspective, the idea of perceptual conspicuousness is significant since Brubaker et al. (2004), along with others, have shown that perception is conditioned by conceptual categories and classifications that are socially-informed which means that what and how things are perceived will, to some extent, reflect the power relations existing in a given society. According to Mills (2007), it is this fact of social cognition (conception, perception) that helps to explain what was previously described as an "epistemology of ignorance" under conditions of systemic racism or white supremacy. As to the matter of classification, it is interesting to note, again, that according to Bateson, "there are differences between differences. Every effective difference denotes a demarcation, a line of classification, and all classification is hierarchic. In other words, differences are themselves to be differentiated and classified" $(1972,324)$.

\footnotetext{
${ }^{35}$ Lanier (2000) insists that a distinction must be made between cybernetics and cybernetic totalism; however, from a critical race theoretical perspective, it is at least conceivable that this distinction may turn out to be analogous to the distinction between refined/covert (invisible) and crude/overt (visible) forms of racism.

${ }^{36}$ As Johar Schueller states, "the colonizers speak for all humanity and the colonized simply talk about their own condition. The universalizing impulse implicitly draws on the legacy of colonialism and the project of modernity, albeit in a globalized, postcolonial world" $(2005,64)$. The tendency to conflate the Eurocentric particular with the universal is explored in Wallerstein (2005) among other works.

${ }^{37}$ It must be recognised, however, that some postcolonial - or rather, decolonial - theorists such as Mignolo consider that certain strands of second-order (or reflexive) cybernetic thinking, such as the theory of autopoiesis proposed by Maturana and Varela, may possess a liberating potential vis-à-vis the project of epistemic decolonisation.
} 
This leads to consideration of yet another important issue, viz. the difference - or perhaps that should be distinction - between the terms difference and distinction ${ }^{38}$. On one conception, differences can be taken as given (or natural), whereas distinctions are held to be made (or constructed). This formulation is useful since it points to a social origin for the semantics of distinction that resonates strongly with ordinary (or folk) usage of the term as indicating a difference of status or position as in, for example, expressions such as "a person of distinction". Delving deeper, such a conception functions to motivate consideration of who it is within society that is responsible for making (or constructing) distinctions - that is, which individuals and groups - leading to an analysis of socio-political stakeholders and the asymmetric power relations that exist among them.

Building on Bateson's Kant-inspired reference to the infinity of differences associated with a thing, Wilden maintains that "we recognize that there are no 'facts' in science, only an infinity of possible differences (and types of difference) among which to choose to make DISTINCTIONS, and that our choice to transform or translate a particular difference into a distinction cannot be constrained by our 'hypotheses', both individual and collective ... ALL KNOWLEDGE IS INSTRUMENTAL. In the terms of modern communications theory, information (coded variety) is everywhere, but knowledge can only occur within the ecosystemic context of a goal-seeking adaptive system peopled by goal-seeking subsystems. If this is the case, then we are required to ask how the knowledge has been coded and filtered; and what it is being used for, and for whom" (1972, xxix).

In addition to the shift in focus from difference to distinction and from information to knowledge, mention of "our choice" in the above quote is significant since it implies a historical contingency and volitional component in the construction of distinctions, as well as the necessary existence of a group responsible for such constructions. However, the characteristics of this group - specifically, its racial composition - remains unstated, thereby giving the unwarranted impression that it is composed of all kinds of people, each of whom stands on an equal footing; power relations - or rather, power differentials - remain both masked and unexplored. Nonetheless, Wilden's conception of a teleological (that is, purposeful or goal-seeking) ecosystem peopled by teleological subsystems is important since it links distinction and difference to human systemic concerns, which from a critical race theoretical perspective means linking to systemic formulations of race as white supremacy presented by Fuller Jr., Mills and others.

\subsection{Information, Embodiment and Race}

One explanation for the lack of engagement with information theory from a critical race theoretical perspective lies in the widespread tendency to view information as necessarily abstract and disembodied. For example, as previously stated, Bateson (1972) held that the elementary unit of information is "a difference that makes a difference" and that this difference is an "abstract matter" (p.458, emphasis added). However, Hayles (1999) contests this view, arguing that information was originally concrete and embodied, and that it gradually lost its 'body' as a consequence of a shift from a worldview that prioritised presence (or materiality) to one that prioritises pattern (or form) ${ }^{39}$. From the perspective of critical race theory, the loss of information's 'body' is significant since it involves an overt shift from the concrete and embodied to the abstract and disembodied which masks a covert shift from the particular and raced to the (allegedly) universal and race-less (or deraced). To the extent that racialization can be viewed as an informational - that is, in-formational process, information's loss of body can be understood as a process of overt (or visible) deracialization that masks a process of covert (or invisible) re-racialization.

Mills' (1997) historically-informed methodological hypothesis about the "epistemology of ignorance" as involving the construction of cognitively dysfunctional (yet socio-politically functional) "colour-blind" categories and classifications following the "signing" of the "Racial Contract" is relevant for understanding how, but perhaps more importantly why, information became disembodied. Conversely, the significance of moves to re-embody information - for example, in theories of embodied cognition, at least some of which have Kantian foundations - in terms of a "re-writing" of the "Racial Contract" needs to be considered since the body invoked in such theories is tacitly assumed to be race-less, much in the same way that mainstream social contract theory is based on the presumption of a de-raced 'person' as ontologically primitive.

Finally, the significance of race, racism and processes of racialization for thinking about the relation between information and embodiment, and the relevance of this for yet further "re-writing" of the "Racial Contract", also re-surfaces in the context of debates about identity, the socio-political

\footnotetext{
${ }^{38}$ In addition, there is a need to consider how difference and distinction relate to Derrida's concept of différance with its dual connotations of displacement and deferral in connection with signifiers and processes of signification (Wilden 1972).

${ }^{39}$ This shift was engendered by the emergence of cybernetic and computational conceptions of phenomena.
} 
logic of biometric technologies (Pugliese 2005, 2007; Browne 2009), and the new conceptions of race engendered by the HapMap Project's search for genetic differences between 'racial' groups. The latter development is particularly disturbing since it appears to mark a shift back to biological conceptions of race through 'informationalization' of the latter ${ }^{40}$. According to Chow-White, "the convergence of changing concepts of race with information technologies has produced a new paradigm for race - what I refer to as the informationalization of race. This paradigm, while it emerges in discourses of the information age that present themselves as color-blind, is, I argue, in fact, a product of new regimes of racial knowledge that are oriented around the digital cultures of communication technologies, especially the Internet and databases, both in everyday practices and social institutions" (2008, 1169-1170).

\section{Conclusion}

This paper has attempted to explore issues at the intersection of race and information by adopting a reflexive hermeneutic approach involving the analysis of race from a critical information theoretical perspective, while analyzing information from a critical race theoretical perspective. It has been shown that systemic conceptions of race and racism are readily interpreted in terms of information theoretical concepts and processes, but that racial concepts and processes may be embedded within information theory, including critical information theory. However, further studies which make use of the reflexive hermeneutic approach presented herein need to be carried out in order to substantiate these claims more fully.

\section{References}

Ali, Syed Mustafa. 2012. Towards a Critical Race Theory of Information. $4^{\text {th }}$ ICTs and Society Conference, Uppsala University, 2-4 May 2012. Accessed July 5, 2012. http://www.icts-and-society.net/wp-content/uploads/presentations/P1.pdf.

Back, Les. 2002. Aryans Reading Adorno: Cyber-Culture and Twenty-First Century Racism. Ethnic and Racial Studies 25(4): 628-651.

von Baeyer, Hans Christian. 2003. Information: The New Language of Science. London: Phoenix.

Banton, Michael. 1998. Racial Theories. Cambridge: Cambridge University Press.

Banton, Michael. 2004. Race: As Classification. In Encyclopedia of Race and Ethnic Studies, edited by Ellis Cashmore, 333334. London: Routledge.

Bateson, Gregory. 1972. Steps to An Ecology of Mind: Collected Essays in Anthropology, Psychiatry, Evolution, and Epistemology. New Jersey: Jason Aronson Inc.

Bernasconi, Robert. 2001a. Race. Oxford: Blackwell.

Bernasconi, Robert. 2001b. Who Invented the Concept of Race? Kant's Role in the Enlightenment Construction of Race. In Race, edited by Robert Bernasconi, 11-36. Oxford: Blackwell.

Bernasconi, Robert. 2003a. Will the Real Kant Please Stand Up: The Challenge of Enlightenment Racism to the Study of the History of Philosophy. Radical Philosophy 117: 13-22.

Bernasconi, Robert. 2003b. Hegel's Racism: A Reply to McCarney. Radical Philosophy 119: 35-37.

Bernasconi, Robert, and Sybol Cook. 2003. Race and Racism in Continental Philosophy. Bloomington and Indianopolis: Indiana University Press.

Bernasconi, Robert. 2011. Kant's Third Thoughts on Race. In Reading Kant's Geography, edited by Stuart Elden and Eduardo Mendieta, 291-318. Albany: SUNY Press.

Blaut, James Morris. 1992. The Theory of Cultural Racism. Antipode: A Radical Journal of Geography 23: 289-299.

Boxill, Bernard. 2001. Race and Racism. Oxford: Oxford University Press.

Browne, Simone. 2009. Digital Epidermalization: Race, Identity and Biometrics. Critical Sociology 36(1): 131-150.

Brubaker, Rogers, Mara Loveman, and Peter Stamatov. 2004. Ethnicity as Cognition. Theory and Society 33: 31-64.

Capurro, Rafael. 2009. Past, Present, and Future of the Concept of Information. tripleC 7(2): 125-141. Accessed August 9 , 2012. http://www.triple-c.at/index.php/tripleC/article/view/113

Capurro, Rafael, and Birger Hjørland. 2003. The Concept of Information. In Annual Review of Information Science and Technology (ARIST) 37, edited by Blaise Cronin, 343-411. Medford, NJ: Information Today.

Carter, Bob. 2000. Realism and Racism: Concepts of race in sociological research. London: Routledge.

Chalmers, David. 1996. The Conscious Mind: In Search of a Fundamental Theory. Oxford: Oxford University Press.

Chapman, David. 2011. Information, Meaning and Context. In Perspectives on Information, edited by Magnus Ramage and David Chapman, 36-50. New York: Routledge.

Chow-White, Peter. 2008. The Informationalization of Race: Communication Technologies and the Human Genome in the Digital Age. International Journal of Communication 2: 1168-1194.

Compaine, Benjamin. 2001. The Digital Divide: Facing a Crisis or Creating a Myth? Cambridge, MA: MIT Press.

\footnotetext{
${ }^{40}$ As stated earlier, Hesse (2011) argues that there was a shift in the early twentieth-century to a biological and intraEuropean concept of racism associated with Nazi anti-Semitism which resulted in the occlusion of antecedent forms of nonEurocentric colonial racism. Although his argument is convincing, it is important to appreciate that biological conceptions of race and intra-European racism are only contingently-related. As Chow-White (2008) has shown, under the 'informationalization' of race - which according to the position argued for herein also involves the racialization of information - biological conceptions of race can re-emerge - in fact, have re-emerged - in the context of global projects associated with human genomics.
} 
Daniels, Jessie. 2009. Cyber Racism: White Supremacy Online and the New Attack on Civil Rights. Lanham: Rowman \& Littlefield.

Eglash, Ron. 1995. African Influences in Cybernetics. In The Cyborg Handbook, edited by Chris Hables Gray, 17-27. New York: Routledge.

Eglash, Ron, and Julian Bleecker. 2001. The Race for Cyberspace: Information Technology in the Black Diaspora. Science as Culture 10(3): 353-374.

Eze, Emmanuel Chukwudi. 1997. Race and the Enlightenment: A Reader. London: Blackwell.

Floridi, Luciano. 2002. What is The Philosophy of Information? Metaphilosophy 33(1/2): 123-145.

Floridi, Luciano. 2003. Two Approaches to the Philosophy of Information. Minds and Machines 13: 459-469.

Floridi, Luciano. 2004a. Information. The Blackwell Guide to the Philosophy of Computing and Information, edited by Luciano Floridi, 40-61. Oxford: Blackwell.

Floridi, Luciano. 2004b. Open Problems in the Philosophy of Information. Metaphilosophy 35(4): 554-582.

Floridi, Luciano. 2009. Philosophical Conceptions of Information. In Formal Theories of Information, LNCS 5363, edited by Giovanni Sommaruga, 13-53. Berlin: Springer-Verlag.

Floridi, Luciano. 2010a. Information: A Very Short Introduction. Oxford: Oxford University Press.

Floridi, Luciano. 2010b. The Philosophy of Information: Ten Years Later. Metaphilosophy 41(3): 402-419.

Fortier, Francois. 2001. Virtuality Check: Power Relations and Alternative Strategies in the Information Society. London: Verso.

Fuchs, Christian. 2009. Towards a Critical Theory of Information. tripleC 7(2), 243-292. Accessed August 9, 2012. http://www.triple-c.at/index.php/tripleC/article/view/91

Fuller, Jr., Neely. 1984. The United Independent Compensatory Code/System/Concept: A Textbook/Workbook for Thought, Speech and/or Action for Victims of Racism (White Supremacy). Washington, D.C.: Neely Fuller, Jr.

Garcia, Jorge. 1996. Heart of Racism. Journal of Social Philosophy 25: 5-45.

Gerovitch, Slava. 2002. From Newspeak to Cyberspeak: A History of Soviet Cybernetics. Cambridge, MA: MIT Press.

Goldberg, David Theo. 2002. The Racial State. Oxford: Blackwell.

Griffin, David Ray. 1998. Unsnarling the World-Knot: Consciousness, Freedom and the Mind-Body Problem. Berkeley: University of California Press.

Hall, Stuart. 1973. Encoding and Decoding in the Media Discourse. In Stencilled Paper 7, Birmingham: Centre for Contemporary Cultural Studies.

Hall, Stuart. 2002. Race, the Floating Signifier. Accessed July 20, 2011 http://www.mediaed.org/assets/products/407/transcript 407.pdf

Hargittai, Eszter. 2008. The Digital Reproduction of Inequality. In Social Stratification, edited by David Grusky, 936-944. Boulder: Westview Press.

Harris, Leonard. 1999. Racism (Key Concepts in Critical Theory). New York: Humanity Books.

Hayles, Katherine. 1999. How We Became Posthuman: Virtual Bodies in Cybernetics, Literature and Informatics. Chicago: University of Chicago Press.

Heidegger, Martin. 1977. The Question Concerning Technology and Other Essays. New York: Harper \& Row.

Heims, Steve. 1993. Constructing a Social Science for Postwar America: The Cybernetics Group, 1946-1953. Cambridge, MA: MIT Press.

Hesse, Barnor. 2007. Racialized Modernity: An Analytics of White Mythologies. Ethnic and Racial Studies 30(4): 643-663.

Hesse, Barnor. 2011. Self-Fulfilling Prophecy: The Postracial Horizon. The South Atlantic Quarterly 110(1): 155-178.

Hill, Thomas Jr., and Bernard Boxill. 2001. Kant and Race. In Race and Racism, edited by Bernard Boxill, 448-471. New York: Oxford University Press.

Hobson, John. 2007. Is Critical Theory Always For the White West and For Western Imperialism? Beyond Westphilian, Towards a Post-Racist, International Relations. Review of International Studies 33(SI): 91-116.

Hofkirchner, Wolfgang. 2009. How to Achieve a Unified Theory of Information. tripleC 7(2): 357-368. Accessed August 9 , 2012. http://www.triple-c.at/index.php/tripleC/article/view/114

Hofkirchner, Wolfgang. 2011a. Four Ways of Thinking about Information. tripleC 9(2): 322-331. Accessed August 9, 2012. http://www.triple-c.at/index.php/tripleC/article/view/281

Hofkirchner, Wolfgang. 2011b. Emergent Information: A Unified Theory of Information Framework. World Scientific Series in Information Studies Vol.3. Singapore: World Scientific.

Johar Schueller, Malini. 2005. Analogy and (White) Feminist Theory: Thinking Race and the Color of the Cyborg Body. Signs 31(1): 63-92.

Kleingeld, Pauline. 2007. Kant's Second Thoughts on Race. The Philosophical Quarterly 57(229): 573-592.

Kolko, Beth, Lisa Nakamura, and Gilbert Rodman. 2000. Race in Cyberspace. New York: Routledge.

Lanier, Jaron. 2000. One Half of a Manifesto. Edge Journal. Accessed December 16, 2011. http://www.edge.org/3rd culture/lanier/lanier index.html

Larrimore, Mark. 1999. Sublime Waste: Kant on the Destiny of the 'Races'. Canadian Journal of Philosophy 25: 99-125.

Larrimore, Mark. 2008. Antinomies of Race: Diversity and Destiny in Kant. Patterns of Prejudice, 42 (4-5), 341-363.

Lash, Scott. 2002. Critique of Information. London: Sage.

Leckie, Gloria, Lisa Given, and John Buschman. 2010. Critical Theory for Library and Information Science: Exploring the Social from Across the Discipline. Santa Barbara: Libraries Unlimited.

Levine, Michael, and Tamas Pataki. 2004. Racism in Mind. Ithaca: Cornell University Press.

Louden, Robert. 2000. Kant's Impure Ethics: From Rational Beings to Human Beings. New York: Oxford University Press.

Malik, Sarita. 2004. Racial Coding. In Encyclopedia of Race and Ethnic Studies, edited by Ellis Cashmore, pp.341-345. London: Routledge.

Maturana, Humberto, and Francisco Varela. 1980. Autopoiesis and Cognition: the Realization of the Living. Boston Studies in the Philosophy of Science 42. Dordecht: D. Reidel Publishing.

Mignolo, Walter. 2010. Delinking: The Rhetoric of Modernity, the Logic of Coloniality and the Grammar of De-Coloniality. In Globalization and the Decolonial Option, edited by Walter Mignolo and Arturo Escobar, 303-368. London: Routledge. 
Miles, Robert. 2004. Racialization. In Encyclopedia of Race and Ethnic Studies, edited by Ellis Cashmore, 348-349. London: Routledge.

Miles, Robert, and Malcolm Brown. 2003. Racism (Second Edition). London: Routledge.

Mills, Charles. 1997. The Racial Contract. Ithaca: Cornell University Press.

Mills, Charles. 1998. Blackness Visible: Essays on Philosophy and Race. Ithaca: Cornell University Press.

Mills, Charles. 2003. From Class to Race: Essays in White Marxism and Black Radicalism. Lanham, MD: Rowman and Littlefield.

Mills, Charles. 2005. Kant's Untermenschen. In Race and Racism in Modern Philosophy, edited by Andrew Valls, 169-93. Ithaca: Cornell University Press.

Mills, Charles. 2007. White Ignorance. In Race and Epistemologies of Ignorance, edited by Shannon Sullivan and Nancy Tuana, 13-38. Albany: SUNY Press.

Mills, Charles, and Carole Pateman. 2007. Contract and Domination, Malden: Polity Press.

Moss, Jeremy. 2002. Power and the Digital Divide. Ethics and Information Technology 4: 159-165.

Nakamura, Lisa. 2002. Cybertypes: Race, Ethnicity and Identity on the Internet. New York: Routledge.

Nakamura, Lisa. 2007. Digitizing Race: Visual Cultures of the Internet. Minneapolis: Minnesota University Press.

Nakamura, Lisa, and Peter Chow-White. 2011a. Race After the Internet. New York: Routledge.

Nakamura, Lisa, and Peter Chow-White. 2011b. Introduction - Race and Digital technology: Code, the Color Line, and the Information Society. In Race After the Internet, edited by Lisa Nakamura and Peter Chow-White, 1-18. New York: Routledge.

Omi, Michael, and Howard Winant. 1994. Racial Formation in the United States: From the 1960s to the 1990s. London: Routledge.

Outlaw, Lucius. 1996. On Race and Philosophy. New York: Routledge.

Pugliese, Joseph. 2005. In Silico Race and The Heteronomy of Biometric Proxies: Biometrics in The Context of Civilian Life, Border Security and Counter-Terrorism Laws. The Australian Feminist Law Journal 23: 1-32.

Pugliese, Joseph. 2007. Biometrics, Infrastructural Whiteness, and the Racialized Zero Degree of Nonrepresentation. Boundary 2(34): 105-133.

Ramage, Magnus. 2011. Competing Models of Information in the History of Cybernetics. In Perspectives on Information, edited by Magnus Ramage and David Chapman, 8-20. New York: Routledge.

Rattansi, Ali. 2007. Racism: A Very Short Introduction. Oxford: Oxford University Press.

Rocchi, Paolo. 2011. The Concepts of Signifier and Signified Revisited. In The Difference that Makes a Difference: An Interdisciplinary Workshop on Information and Technology. Accessed November 29, 2011. http://cobra4.open.ac.uk/DTMD2011/Presentations/Session\%202/Rocchi.pdf

Shannon, Claude, and Warren Weaver. 1949. The Mathematical Theory of Communication. Urbana: University of Illinois Press.

Shelby, Tommie. 2002. Is Racism in the "Heart"? Journal of Social Philosophy 33(3), 411-420.

Taylor, Paul. 2004. Race: A Philosophical Introduction. Cambridge: Polity Press.

Taylor, Paul. 2011. The Philosophy of Race. New York: Routledge.

Tibebu, Teshale. 2011. Hegel and the Third World. Syracuse: Syracuse University Press.

Valls, Andrew. 2005. Race and Racism in Modern Philosophy. Ithaca: Cornell University Press.

Van Cleve, James. 1990. Mind-Dust or Magic? Panpsychism versus Emergence. Philosophical Perspectives 4: 215-226.

Van Den Berghe, Pierre. 2004. Race: As Signifier. In Encyclopedia of Race and Ethnic Studies, edited by Ellis Cashmore, 334-335. London: Routledge.

Wallerstein, Immanuel. 2005. European Universalism: The Rhetoric of Power. New York: The Free Press.

Ward, Julie, and Tommy Lott. 2002. Philosophers on Race: Critical Essays. Oxford: Blackwell.

Warschauer, Mark. 2003. Technology and Social Inclusion: Rethinking the Digital Divide. Cambridge, MA: MIT Press.

Wilden, Anthony. 1972. System and Structure: Essays in Communication and Exchange. London: Tavistock Publications.

Winant, Howard. 2001. The World is a Ghetto: Race and Democracy Since World War II. New York: Basic Books.

Winant, Howard. 2004. The New Politics of Race: Globalism, Difference, Justice. Minneapolis: University of Minnesota Press.

\section{About the Author}

Syed Mustafa Ali

is a lecturer in the Computing Department of The Open University (UK). His current research focuses on the development of a hermeneutic framework that can be used to inform critical investigations of computational, informational, cybernetic, systems-theoretical and Trans-/Post-human phenomena. The framework is grounded in phenomenology, critical race theory and postcolonial thought and is being used to analyse computational social science phenomena (multi-agent systems), power relations within digital politics/activism and discourses on the "digital divide". Previous research interests include the artificial sciences (Al, A-Life and virtual reality), philosophy of mind (process models of consciousness), conceptual foundations of emergence, and philosophy of technology (artefact ontology). 